\title{
Studi Perbandingan Perusahaan Perseorangan (Sole Proprietorship) Dan Koperasi (Cooperative) Pada Negara Laos \& Indonesia
}

\author{
Andi Rahmat Heriawan \\ Mahasiswa Magister Hukum, Fakultas Hukum Universitas Indonesia, \\ Email: andirahmatheriawan322@gmail.com
}

\begin{abstract}
This study focused to conduct a comparative study of the legal form about individual company (Sole Proprietorship) and a Cooperative. This research using Normative legal research to examine legal rules related to corporate law in a country. The legal form of an individual company (sole proprietorship) is contained in the Laos "Enterprise Law" which was amended in 2013. Meanwhile, the cooperative in Laos is based on the "Enterprise Law", but the implementing regulations are subject to the "Decree On Cooperative" provisions, was made in 2009. The legal form of an individual company (sole proprietorship) in Indonesia is in Law No.3 of 1982, while cooperatives are contained in Law No.17 of 2017 concerning Cooperatives. The result of the research is that there are some fairly basic differences between individual companies (Sole Proprietorship) and Cooperative in Indonesia and Laos. This research have several comparative indicators can include the legal basis, company business activities, sources of capital, profits, losses, tax systems, and financing systems.
\end{abstract}

\begin{abstract}
Abstrak. Penelitian ini bertujuan untuk melakukan studi komparatif tentang bentuk hukum pendirian perusahaan perseorangan (Sole Proprietorship) dan koperasi (Cooperative). Penelitian ini menggunakan penelitian hukum Normatif mengkaji aturan-aturan hukum yang berkaitan dengan hukum perusahaan pada suatu Negara. Bentuk hukum dari perusahaan perseorangan (sole proprietorship) tertuang pada "Enterprise Law" Laos yang diamandemen pada tahun 2013. Sedangkan koperasi (cooperative) di Laos bentuk hukumnya berdasarkan pada "Enterprise Law", namun pada peraturan pelaksanaannya tunduk pada ketentuan "Decree On Cooperative" yang dibuat pada tahun 2009. Bentuk hukum dari perusahaan perseorangan (sole proprietorship) di Indonesia ada pada Undang-Undang No.3 Tahun 1982, sedangkan koperasi (cooperative) tertuang dalam Undang-Undang No.17 Tahun 2017 Tentang Perkoperasian. Hasil penelitian yaitu terdapat beberapa perbedaan yang cukup mendasar antara perusahaan perseorangan (Sole Proprietorship) dan koperasi (Cooperative) di Indonesia dan Laos. Secara garis besar beberapa indicator perbandingan dapat mencakup tentang dasar hukum, aktivitas bisnis perusahaan, sumber permodalan, keuntungan, kerugian, sistem perpajakan, dan sistem pembiayaan.
\end{abstract}

Kata Kunci: Perbandingan; Sole Proprietorship; Cooperative

\section{PENDAHULUAN}

Laos merupakan negara dengan predikat negara terkecil kedua di Asia Tenggara setelah Brunei. Laju dan tingkat pertumbuhan penduduk Laos berkembang pesat sejak awal tahun 2000an dengan rata-rata pertumbuhan Pendapatan Domestik Bruto (PDB) Laos sebanyak 7\% setiap tahunnya. Pertumbuhan dan perkembangan yang pesat tersebut adalah hasil dari kebijakan pemerintah Laos yang menaruh kebijakan Pro Investasi terhadap masuknya perusahaan asing yang ingin melakukan investasi di Laos. Tak hanya sampai disitu, IMF pada Oktober 2017 yang lalu menyimpan harapan besar kepada Laos agar tetap menjadi negara dengan pertumbuhan ekonomi tercepat di kawasan Asia Timur dengan proyeksi pertumbuhan PDB tetap konsisten di angka 7\% pada tahun 2018 sampai menjelang tahun 2022. Hal ini tentunya semakin membuka kesempatan bagi Laos sebagai negara destinasi investasi dibanyak sekto perekonomian, baik itu meliputi industri, energi, transportasi, dan industri manufaktur lainnya.

Dengan hadirnya Laos sebagai negara berkembang yang siap menampung investasi dari luar, maka pemerintah mensiasati dengan melakukan update kebijakan investasi yang memungkinkan investor untuk cakap dan memiliki wawasan terbaru tentang persyaratan peraturan dan hukum investasi di Laos. 
Mendirikan perusahaan di negara Laos pada umumnya relatif tidak mudah untuk melakukannya. Ada banyak jenis-jenis perusahaan yang diakui dalam peraturan perundang-undangan Laos, namun yang paling umum dan banyak didirikan adalah jenis perusahaan perseorangan (Sole Proprietorship). Namun, tak terkecuali banyak juga perusahaan yang berdiri di Laos. Salah satunya adalah koperasi yang menjadi lumbung pemberdayaan manusia melalui sektor-sektor pertanian, kehutanan, jasa, dan pertambangan. Bayangkan saja, untuk menghadirkan sebuah perusahaan baru di Laos, dibutuhkan waktu sekitar 60 hari lebih agar dapat terealisasi.

Untuk mencapai tujuan pembangunan nasional diperlukan kerjasama masyarakat dan pemerintah. Masyarakat sebagai pelaku utama pembangunan ekonomi dan pemerintah selaku regulator berkewajiban mengarahkan, membimbing, melindungi agar langkah kegiatan dapat serasi dalam satu kesatuan langkah menuju tercapainya pembangunan nasional. Dalam praktek di Indonesia ada tiga bentuk usaha, yaitu usaha swasta, usaha Negara, dan usaha koperasi. Dilihat dari segi hukum perusahaan masing-masing dari bentuk usaha tersebut memiliki pengaturan yang berbeda menyangkut pendirian hak dan kewajiban pihakpihak, tanggung jawab, pembubaran dan sebagainya. Bentuk usaha swasta ini adalah bentuk usaha yang modalnya dimiliki seluruh atau sebagian besar oleh pihak swasta baik secara individu (perseorangan) maupun kelompok. Yang termasuk kelompok bentuk usaha swasta ini adalah Perusahaan Perseorangan atau Usaha Dagang (UD), Persekutuan Firma (Fa), Persekutuan Komanditer (CV), dan Perseroan Terbatas (PT). Selain itu, ada juga jenis perusahaan yang berbentuk koperasi. Koperasi adalah organisasi ekonomi yang memiliki ciri-ciri yang berbeda dengan organisasi ekonomi lain. Perbedaan ini terletak pada sistem nilai etis yang melandasi kehidupannya dan terjabar dalam prinsipprinsipnya yang kemudian berfungsi sebagai norma-norma etis yang mempolakan tata laku koperasi sebagai ekonomi. Ciri utama koperasi adalah kerjasama anggota dengan tujuan untuk mencapai kesejahteraan hidup bersama. Sebagai suatu perusahaan, koperasi harus menjalankan sesuatu usaha yang mendatangkan keuntungan ekonomis, meskipun koperasi bukan merupakan bentuk akumulasi modal. Untuk mencapai tujuan mendatangkan keuntungan ekonomis tersebut, maka koperasi harus menjalankan usahanya secara terus menerus (kontinyu), terang-terangan, berhubungan dengan pihak ketiga, dan memperhitungkan rugi laba serta mencatat semua kegiatan usahanya tersebut ke dalam suatu pembukuan.

Dari pembahasan diatas, penulis melihat 2 (dua) pokok pembahasan yakni pada perusahaan perseorangan (sole proprietorship) dan koperasi (cooperative). Sehingga penulis menjelaskan rumusan masalah pada penelitian ini sebagai berikut : Bagaimana bentuk hukum pengaturan perusahaan perseorangan (Sole Proprietorship) dan koperasi (Cooperative) di Laos dan Indonesia? Bagaimana perbandingan perusahaan perseorangan (Sole Proprietorship) $\&$ koperasi (Cooperative) antara Laos dan Indonesia?

\section{METODE PENELITIAN}

Pendekatan dan Jenis Penelitian dalam hal ini pendekatan yang dipergunakan dalam penelitian ini adalah pendekatan perundang-undangan (statute approach). Pendekatan perundanganundangan adalah pendekatan yang dilakukan dengan menelaah semua undang-undang dan regulasi yang bersangkut paut dengan masalah hukum yang ditangani. Jenis penelitian menggunakan penelitian hukum Normatif mengkaji aturan-aturan yang berkaitan dengan hukum perusahaan pada suatu Negara.

Jenis dan Sumber Bahan Hukum yaitu Bahan hukum Primer adalah bahan yang bersumber dari Kitab Undang-Undang Hukum Acara Perdata, Undang-Undang No.17 Tahun 2017 Tentang Perkoperasian, Undang-Undang No.3 Tahun 1982 Tentang Daftar Perusahaan, Decision on Enterprise Registration 2019, Lao People's Democratic Republik, Decree On 
Cooperative 2009, Lao People's Democratic Republic, Enterprises Law (Amended) 2013, Lao People's Democratic Republic, Tax Law (Amended) 2015, Lao People's Democratic Republic. Bahan hukum Sekunder adalah yang diperoleh dari menganalisis buku hukum. Data Tersier adalah yang diperole $h$ dari kamus hukum, jurnal hukum dan literatur (internet).

Penelitian ini bertujuan untuk melakukan studi komparatif tentang bentuk hukum pendirian perusahaan perseorangan (Sole Proprietorship) dan koperasi (Cooperative). Dengan menerapkan system hukum yang berbeda dengan Indonesia, tentunya sangat menarik untuk mengkaji lebih dalam tentang apa saja bentuk persamaan atau perbedaan antara kedua Negara tersebut.

Analisis Bahan Hukum dalam penelitian ini, peneliti mengolah dan menganalisis bahan hukum dengan langkah berpikir sistematis, dimana bahan hukum primer dianalisis dengan langkah - langkah normatif dan dilanjutk an dengan pembahasan secara deskriftif analitis. Terhadap bahan hukum sekunder dilakukan dengan penelaahan dengan mengacu terhadap pokok bahasan permasalahan. Bahan hukum tersier dilakukan penelaahan dengan mengacu kepada petunjuk yang mampu menjelaskan tentang istilahistilah. Bahan-bahan hukum tersebut kemudian diolah dan dibahas dengan metode analisis isi (content analysis) yaitu menelaah peraturan perundang - undangan yang dimaksud.

\section{HASIL DAN PEMBAHASAN}

\section{A. Bentuk Hukum Perusahaan Perseorangan (Sole Proprietorship) \& Koperasi (Cooperative) Di Laos. \\ 1. Perusahaan Perseorangan (Sole Proprietorship)}

Dalam penjelasan peraturan perundangundangan Laos tentang "Enterprise Law" pada tahun 2013 disebutkan dalam penjelasan umum bahwa yang dimaksud dengan perusahaan perseorangan (sole proprietorship, sole trade enterprise, atau individual enterprise) yaitu :

"is a form of enterprise created by one person. Individual enterprise conducts business in the interests of an owner. The owner is solely and unlimitedly responsible for the enterprise's liabilities."

Jelas bahwa perusahaan tersebut didirikan oleh satu individu yang bertindak sebagai pemilik, sehingga bertanggungjawab atas pembiayaan dan pengelolaan bisnis perusahaan itu sendiri.

Perusahaan perseorangan di Laos juga memiliki kelebihan dan kekurangan yaitu sebagai berikut :

1) Keuntungan :

- Proses administrasi pendaftaran sederhana.

- Memiliki kontrol penuh terhadap keputusan perusahaan.

- Mudah dibentuk dengan tingkat formalitas yang rendah.

- Keuntungan akan kembali kepada pemilik.

- Tidak mengharuskan untuk melakukan publikasi laporan keuangan.

2) Kerugian :

- Sumber permodalan sangat terbatas karena berdasar pada kontribusi pemilik itu sendiri.

- Pemilik dapat dianggap bertanggungjawab atas hutang yang dialami perusahaan.

- Pengembangan bisnis tergantung pada seberapa besar kemampuan pemilik untuk mengembangkan perusahaan.

- Bisnis akan dibubarkan setelah pemilik telah tiada.

Dalam mendirikan sebuah perusahaan, harus terlebih dahulu melakukan proses registrasi. Registrasi yang dimaksudkan adalah proses penerimaan pendirian perusahaan yang sah secara hukum khususnya dalam bentuk perusahaan perseorangan dan akan melakukan kegiatan bisnis di wilayah 
kedaulatan Laos. Dari pendaftaran tersebut, kemudian akan terbit sertifikat registrasi perusahaan yang berisi tentang dokumen pendirian perusahaan perseorangan sesuai dengan hukum yang berlaku. Untuk mendirikan sebuah perusahaan perseorangan, maka hal yang perlu diperhatikan adalah sebagai berikut:

1) Nama perusahaan dan kegiatan usaha yang akan dilakukan.

2) Informasi lengkap tentang pendiri perusahaan.

3) Lokasi pendirian perusahaan.

4) Besaran modal perusahaan.

Untuk lebih memahami proses pendirian perusahaan tersebut maka akan dijabarkan sebagai berikut :

1) Untuk melaksanakan pendaftaran perusahaan, khususnya untuk perusahaan perseorangan maka wajib memberikan modal awal minimal senilai 500.000.000,. Kip. Hal tersebut berlaku untuk perusahaan yang berdomisili bisnis di kota Vientiane maupun provinsi lainnya.

2) Departemen Industri dan Perdagangan ataupun otoritas terkait di Laos akan memproses pendaftaran perusahaan berkenaan dengan perusahaan perseorangan yang memiliki alamat bisnis di masing-masing provinsi dan ibukota.

3) Setelah semuanya di proses oleh Departemen Industri dan Perdagangan Laos, akan tetapi terdapat hal permasalahan adanya kabupaten/kota yang belum siap untuk menampung bisnis tersebut, maka Departemen Industri dan Perdagangan Laos akan bertanggungjawab dengan melakukan pertimbangan dan solusi lainnya.

Dokumen-dokumen yang diperlukan untuk pendaftaran perusahaan perseorangan sebagaimana telah diatur oleh Departemen Pendaftaran dan Manajemen Perusahaan Laos yaitu :
1) Formulir aplikasi yang telah di lengkapi untuk pendirian perusahaan.

2) Daftar kegiatan bisnis yang diusulkan akan dilakukan.

Perusahaan perseorangan dalam sistem perpajakan Laos wajib membayarkan sejumlah pajak dari keuntungan perusahaan yang di dapatkan. Keuntungan yang akan disetorkan tidak boleh dikurangkan dengan biaya-biaya perusahaan lainnya sebelum biaya pajak dikeluarkan terlebih dahulu atau telah dihitung sebelumnya. Akan tetapi, jika perusahaan dalam hal ini belum juga menentukan hasil keuntungan/omset dari perusahaan maka pihak otoritas pajak akan melakukan perhitungan sendiri berdasarkan perjanjian wajib pajak yang ada di Laos. Adapun sistem tarif pajak keuntungan untuk perusahaan perseorangan adalah tarif progresif dimana nominalnya dimulai dari $0 \%$ sampai dengan 24\%. Untuk lebih jelasnya dapat dilihat dalam tabel berikut :

Tabel. 1

\begin{tabular}{|c|c|c|c|c|c|}
\hline Level & $\begin{array}{l}\text { Annual Profit } \\
\text { Base }\end{array}$ & $\begin{array}{l}\text { Taxable } \\
\text { Amount }\end{array}$ & Rates & $\begin{array}{l}\text { Tax at Each } \\
\text { Level }\end{array}$ & Total \\
\hline 1 & $\begin{array}{l}\text { From } \\
3,600,000 \text { and } \\
\text { lower }\end{array}$ & $3,600,000$ & $0 \%$ & 0 & 0 \\
\hline 2 & $\begin{array}{ll}\text { From } \\
3,600,001 \quad- \\
8,000,000\end{array}$ & $4,400,000$ & $5 \%$ & 220,000 & 220,000 \\
\hline 3 & $\begin{array}{ll}\text { From } & \\
8,000,001 & - \\
15,000,000 & \\
\end{array}$ & $7,000,000$ & $10 \%$ & 700,000 & 920,000 \\
\hline 4 & $\begin{array}{l}\text { From } \\
15,000,001 \quad- \\
25,000,000\end{array}$ & $10,000,000$ & $15 \%$ & $1,500,000$ & $2,420,000$ \\
\hline 5 & $\begin{array}{l}\text { From } \\
25,000,001 \quad- \\
40,000,000\end{array}$ & $15,000,000$ & $20 \%$ & $3,000,000$ & $5,420,000$ \\
\hline 6 & $\begin{array}{l}\text { From } \\
40,000,001 \\
\text { upward }\end{array}$ & - & $24 \%$ & - & - \\
\hline
\end{tabular}

Setiap orang yang melakukan kegiatan bisnis dan pekerjaan di Laos memiliki tanggungjawab untuk membayarkan pajak penghasilan. Tarif pajak penghasilan di Laos adalah termasuk pajak progresif yang terdiri dari pajak terhadap gaji, upah, tunjangan tambahan, lembur, tunjangan jabatan, tunjangan karir, bonus tambahan, dan tunjangan kegiatan lainnya yang diterima dalam bentuk uang dan barang. Untuk lebih jelas dapat dilihat pada tabel berikut : 
Tabel. 2

\begin{tabular}{|c|c|c|c|c|c|}
\hline Level & $\begin{array}{l}\text { Annual Profit } \\
\text { Base }\end{array}$ & $\begin{array}{l}\text { Taxable } \\
\text { Amount }\end{array}$ & Rates & $\begin{array}{l}\text { Tax at Each } \\
\text { Level }\end{array}$ & Total \\
\hline 1 & $\begin{array}{l}\text { From } \\
1,000,000 \text { and } \\
\text { lower }\end{array}$ & $1,000,000$ & $0 \%$ & 0 & 0 \\
\hline 2 & $\begin{array}{ll}\text { From } & \\
1,000,001 \quad- \\
3,000,000\end{array}$ & $2,000,000$ & $5 \%$ & 100,000 & 100,000 \\
\hline 3 & $\begin{array}{l}\text { From } \\
3,000,001 \\
6,000,000\end{array}$ & $3,000,000$ & $10 \%$ & 300,000 & 920,000 \\
\hline 4 & $\begin{array}{l}\text { From } \\
6,000,001 \quad- \\
12,000,000\end{array}$ & $6,000,000$ & $12 \%$ & 720,000 & $2,420,000$ \\
\hline 5 & $\begin{array}{l}\text { From } \\
12,000,001 \quad- \\
24,000,000\end{array}$ & $12,000,000$ & $15 \%$ & $1,800,000$ & $5,420,000$ \\
\hline 6 & $\begin{array}{ll}\text { From } \\
24,000,001 \quad- \\
40,000,000\end{array}$ & $16,000,000$ & $20 \%$ & $3,200,000$ & $6,120,000$ \\
\hline 7 & $\begin{array}{l}\text { From } \\
40,000,000 \\
\text { and higher }\end{array}$ & - & $24 \%$ & - & - \\
\hline
\end{tabular}

2. Koperasi (Cooperative)

Di negara Laos, koperasi digambarkan sebagai perusahaan kolektif yang bergerak dalam bidang pertanian, kerajinan tangan, pedagang kecil, dan penyedia layanan atau profesi lain dengan maksud untuk memberikan bantuan timbal balik berupa modal,dll. Untuk lebih jelasnya, penjelasan tentang koperasi dapat dilihat di peraturan perundang-undangan Laos tentang "Decree on Cooperative" yaitu :

"Cooperative means collective enterprise of the farmers, handicrafts, small merchants, and service providers and others professions that are voluntarily establish the cooperative in order to provide mutual assistances in capital, experiences and technique in operation of production, trade or service to achieve their business target."

Sehingga kemudian dapat dijabarkan beberapa kategori koperasi yang ada di Laos yakni sebagai berikut :

1) Koperasi yang bergerak di sektor pertanian, kehutanan, industri pengolahan, dan kerajinan tangan.

2) Koperasi yang bergerak di sektor jasa misalnya adalah :
a) Perdagangan
b) Keuangan
c) Transportasi
d) Pariwisata
e) Konstruksi

3) Koperasi yang bergerak di sektor pertambangan.

Selain itu, koperasi juga memiliki memiliki cakupan tentang aturan yang berlaku untuk para anggota dalam rangka memperkuat sektor usahanya. Diantaranya dapat kita lihat yaitu sebagai berikut :

1) Penerimaan anggota secara sukarela.

2) Setiap anggota aktif dalam pengelolaan koperasi wajib memiliki prinsip demokrasi sentral, serta menjadi pemilik dan pelanggan koperasi.

3) Setiap anggota memiliki hak untuk mengoperasikan atau menjalankan bisnis apa pun bersama dengan koperasi.

4) Koperasi bersifat independen atas kegiatan dan menjalankan bisnis.

5) Anggota dewan manajemen harus dipilih oleh anggota koperasi.

6) Koperasi harus terdiri dari setidaknya tujuh anggota, kecuali untuk beberapa jenis koperasi ditentukan oleh peraturan yang mengharuskan memiliki lebih banyak anggota.

Setiap orang yang ingin menjadi anggota koperasi harus mengajukan permohonan kepada koperasi tersebut untuk melakukan pendaftaran sebagaimana ditentukan oleh peraturan koperasi tersebut dan harus memiliki setidaknya satu saham. Keanggotaan harus dimulai sejak tanggal penerimaan, kecuali ditentukan lain oleh Anggaran Dasar / Anggaran Rumah Tangga koperasi tersebut.

Di sisi lain, ada beberapa persyaratan yang harus dipenuhi oleh anggota koperasi yaitu :

1) Koperasi tidak boleh dijadikan badan hukum, kecuali untuk beberapa jenis koperasi.

2) Tidak sedang akan bangkrut atau memiliki hutang melebihi asset yang dimiliki.

3) Harus berusia minimal 18 tahun dan tidak sedang mengalami gangguan psikis.

4) Merupakan warga negara Laos. 
Proses pendirian koperasi bagi warga negara Laos yang akan mendirikan wajib mematuhi prosedur yang berlaku, yaitu :

1) Melakukan pertemuan dan riset tentang bentuk koperasi yang akan di dirikan.

2) Membahas dan menyusun rencana pendirian seperti nama, jumlah anggota, rencana pendirian, daftar modal, jumlah saham, dan rancangan anggaran rumah tangga koperasi.

3) Melakukan pembahasan secara bersamasama tentang anggaran rumah tangga dan mulai menyusun sistem manajemen koperasi.

4) Menyamakan bentuk koperasi dengan sektor usaha terkait.

5) Memberitahukan pendaftaran koperasi dengan dengan sektor industri/usaha yang dipilih.

Mengacu pada pembahasan diatas, maka dokumen yang perlu dipersiapkan adalah :

1) Aplikasi atau form untuk melakukan pendaftaran koperasi.

2) Daftar promotor dan masing-masing tandatangan dari promotor serta jumlah saham/modal yang terdaftar di koperasi.

3) Daftar anggota koperasi.

4) Anggaran rumah tangga koperasi.

5) Izin usaha dari sektor industry terkait.

Selanjutnya, untuk pemberian nama koperasi diserahkan kepada pendiri. Akan tetapi, hal tersebut harus mengikuti arahan peraturan yaitu

1) Mengandung unsur kata "Koperasi"

2) Nama koperasi tidak boleh bertentangan dengan ketentuan undang-undang perusahaan.

Adapun struktur kepengurusan koperasi di Laos terbagi menjadi 3 macam yaitu sebagai berikut :

1) Struktur personalia koperasi terdiri dari : dewan manajemen, inspektur, manajer, akuntan dan petugas teknis, serta orang lain yang diperlukan.

2) Manajer, inspektur, akuntan, dan staf teknis seperti : staf pemasaran atau kredit dapat dipekerjakan dari anggota koperasi atau dari orang luar.

3) Struktur personalia koperasi harus sederhana tetapi memastikan efektivitas kinerja, sesuai untuk jumlah anggota dan status keuangan koperasi.

Modal koperasi di Laos sendiri terbagi atas dua sumber utama yaitu, berasal dari ekuitas dan pinjaman. Ekuitas dari koperasi sendiri diberikan oleh anggota koperasi, cadangan simpanan keuangan, simpanan anggota, serta dana akumulatif untuk pendidikan dan biaya pengembangan koperasi. Sedangkan modal koperasi yang bersumber dari pinjaman adalah modal yang dipinjam dari berbagai sumber lembaga keuangan lainnya. Selain itu, koperasi juga umumnya menghimpun dana hibah atau dukungan dari para pihak dengan tetap berlandaskan pada peraturan perundangundangan yang berlaku.

\section{B. Bentuk Hukum Perusahaan Perseorangan (Sole Proprietorship) \& Koperasi (Cooperative) Di Indonesia.}

\section{Perusahaan Perseorangan (Sole}

\section{Proprietorship)}

Perusahaan perseorangan adalah perusahaan yang didirikan oleh satu individu yang memiliki modal yang cukup untuk melakukan kegiatan bisnis. Pengusaha tunggal akan bertindak sebagai pemilik dan manajer dari kepemilikan perseorangan dan sebagai hasilnya, akan sepenuhnya dapat diandalkan untuk setiap kerugian atau hutang yang mungkin timbul dari kegiatan bisnis perusahaan milik perseorangan. Undang-Undang Nomor 3 Tahun 1982 tentang Wajib Daftar Perusahaan telah menjelaskan tentang perusahaan perseorangan namun dalam konteks dianggap sebagai perusahaan kecil perorangan. Penjelasannya yaitu sebagai berikut :

1) Pasal 6 ayat 1 (b) menjelaskan : "Setiap perusahaan kecil perorangan yang dijalankan oleh pribadi pengusahanya 
sendiri atau dengan mempekerjakan hanya anggota keluarganya sendiri yang terdekat serta tidak memerlukan izin usaha dan tidak merupakan suatu badan hukum atau suatu persekutuan"

2) Pasal 6 ayat 2 menjelaskan : "Perusahaan Kecil Perorangan yang dimaksud dalam ayat (1) huruf (b) pasal ini selanjutnya diatur oleh Menteri dengan memerhatikan peraturan perundangundangan yang berlaku"

Ada beberapa keuntungan dan kerugian dari pendirian perusahaan perseorangan ini, yaitu

1) Keuntungan :

- Pendirian sangat sederhana dan tidak memerlukan ratifikasi dari manapun.

- Pemilik sepenuhnya berhak atas keuntungan yang di dapat.

2) Kerugian

- Kewajiban pemilik tidak terbatas

- Sumber pembiayaan terbatas

- Dapat di dirikan oleh warga negara asing atau entitas asing.

Terkait dengan perdirian perusahaa ini, tidak ada peraturan khusus yang mengatur proses pendirian atau pembentukan perusahaan perseorangan berdasarkan hukum Indonesia. Namun, dalam praktiknya, kepemilikan perseorangan di Indonesia biasanya didirikan berdasarkan prosedur berikut:

1) Menandatangani akta pendirian usaha di depan notaris.

2) Mendaftarkan perusahaan di tempat domisili melakukan bisnis.

3) Memperoleh sertifikat pendaftaran perusahaan.

4) Memperoleh Surat Izin Usaha Perdagangan (SIUP).

5) Memperoleh Surat Izin Tempat Usaha (SITU).

6) Memperoleh Nomor Pokok Wajib Pajak (NPWP) dari kantor pajak.

Struktur dalam perusahaan perseorangan di Indonesia merupakan kebijakan penuh dari pemiliknya. Pemilik dapat mengelola sendiri kegiatan usahanya atau malah mempekerjakan karyawan untuk membantu kegiatan bisnis tersebut. Pada intinya, pemilik perusahaan bertanggungjawab atas manajemen perusahaan yang dimiliki. Meskipun kepemilikan perusahaan perseorangan bukan badan hukum, namun tetap saja diperlakukan sebagai objek yang dikenakan pajak di Indonesia. Keuntungan yang diperoleh dari perusahaan perseorangan akan didistribusikan kepada pemilik dan hal tersebut tidak dikenakan pajak penghasilan. Sumber modal atau pembiayaan dari perusahaan perseorangan timbul dari keuntungan yang di dapat oleh perusahaan dan juga bisa bersumber dari pinjaman lembaga keuangan lainnya. Perlu dicatat, bahwa perusahaan perseorangan di Indonesia dilarang untuk mengumpulkan sumbangan dari publik dalam bentuk apapun.

\section{Koperasi (Cooperative)}

Menurut Pasal 1 ayat 1 Undang-Undang No.17 Tahun 2012 tentang Perkoperasian menyatakan bahwa :

"Koperasi adalah badan hukum yang didirikan oleh orang perseorangan atau badan hukum koperasi, dengan pemisahan kekayaan para anggotanya sebagai modal untuk menjalankan usaha, yang memenuhi aspirasi dan kebutuhan bersama di bidang ekonomi, sosial, dan budaya sesuai nilai dan prinsip koperasi."

Berdasarkan penjelasan diatas, dapat disimpulkan bahwa secara konstitusional koperasi telah diakui kedudukannya.

Dalam Pasal 3 Undang-Undang No.17 Tahun 2012 tentang Perkoperasian disebutkan bahwa :

"Koperasi bertujuan meningkatkan kesejahteraan anggota pada khususnya dan masyarakat pada umumnya, sekaligus sebagai bagian yang tidak terpisahkan dari tatanan perekonomian nasional yang demokratis dan berkeadilan."

Adapun mengenai fungsi koperasi dalam Undang-Undang No.17 Tahun 2012 tentang 
Perkoperasian tidak ditemukan adanya pengaturan secara khusus mengenai fungsi dari koperasi di Indonesia. Hal ini berbeda dengan undang-undang sebelumnya yakni Pasal 4 Undang-Undang No.25 Tahun 1992 tentang Perkoperasian yang menguraikan dengan jelas fungsi-fungsi dari koperasi di Indonesia, yaitu sebagai berikut :

1) Membangun dan mengembangkan potensi dan kemampuan ekonomi anggota pada khususnya dan masyarakat pada umumnya untuk meningkatkan kesejahteraan ekonomi dan sosialnya.

2) Berperan serta secara aktif dalam upaya mempertinggi kualitas kehidupan manusia dan masyarakat.

3) Memperkokoh perekonomian rakyat sebagai dasar kekuatan dan ketahanan perekonomian nasional dengan koperasi sebagai soko-gurunya.

4) Berusaha untuk mewujudkan dan mengembangkan perekonomian nasional, yang merupakan usaha bersama berdasarkan atas asas kekeluargaan dan demokrasi ekonomi.

Selain memiliki peranan dan fungsi, koperasi dalam menjalankan kegiatan usahanya juga memiliki prinsip-prinsip sebagiamana dijelaskan dalam Pasal 6 Undang-Undang No.17 Tahun 2012 tentang Perkoperasian, sebagai berikut :

1) Keanggotaan koperasi bersifat sukarela dan terbuka.

2) Pengawasan oleh anggota diselenggarakan secara demokratis.

3) Anggota berpartisipasi aktif dalam kegiatan ekonomi koperasi.

4) Koperasi merupakan badan usaha swadaya yang otonom, dan independen.

5) Koperasi menyelenggarakan pendidikan dan pelatihan bagi anggota, pengawas, pengurus, dan karyawannya, serta memberikan informasi kepada masyarakat tentang jati diri, kegiatan, dan kemanfaatan koperasi.
6) Koperasi melayani anggotanya secara prima dan memperkuat Gerakan Koperasi, dengan bekerja sama melalui jaringan kegiatan pada tingkat lokal, nasional, regional, dan internasional.

7) Koperasi bekerja untuk pembangunan berkelanjutan bagi lingkungan dan masyarakatnya melalui kebijakan yang disepakati oleh anggota.

Ada dua jenis penyertaan modal dalam koperasi, yaitu penyertaan modal dan penyertaan modal Syariah (secara kolektif disebut sebagai "Penyertaan Modal"). Koperasi dapat memperoleh Penyertaan Modal dari anggota koperasi, masyarakat, setiap badan hukum, dan setiap badan usaha. Kegiatan bisnis yang didanai melalui Partisipasi Modal dikelola oleh koperasi. Investor juga dapat berpartisipasi dalam pengelolaan kegiatan tersebut jika telah disetujui secara tertulis antara koperasi dan investor sebelumnya. Penyedia Penyertaan Modal berhak menerima keuntungan yang didistribusikan dari kegiatan bisnis yang didanai oleh Penyertaan Modal mereka.

C. Perbandingan Perusahaan Perseorangan (Sole Proprietorship) \& Koperasi (Cooperative) Antara Laos Dan Indonesia. Tabel. 3 Perbandingan Perusahaan Perseorangan (Sole Proprietorship)

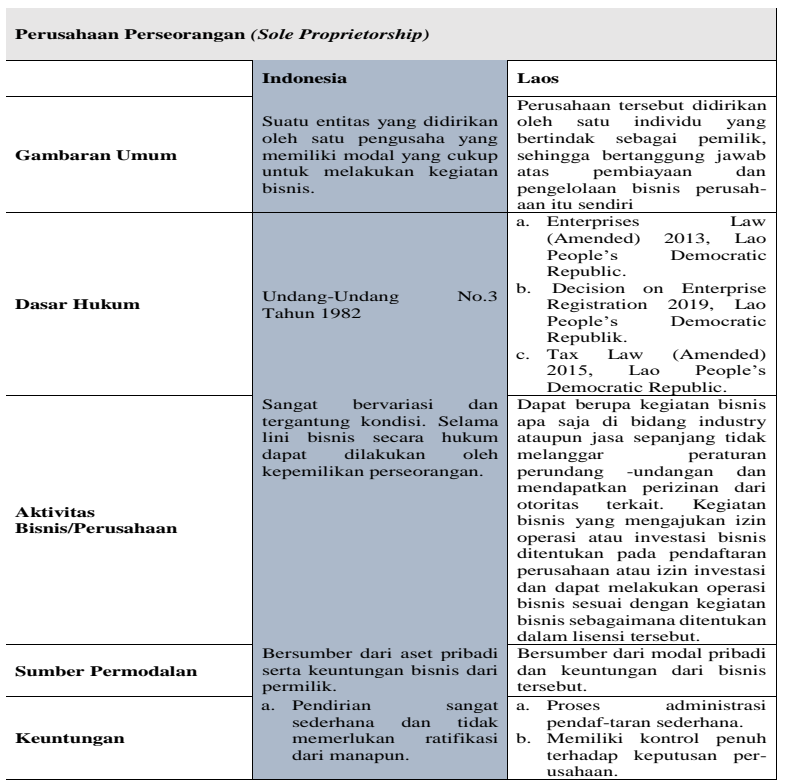


Tabel. 4 Perbandingan Koperasi Cooperative)

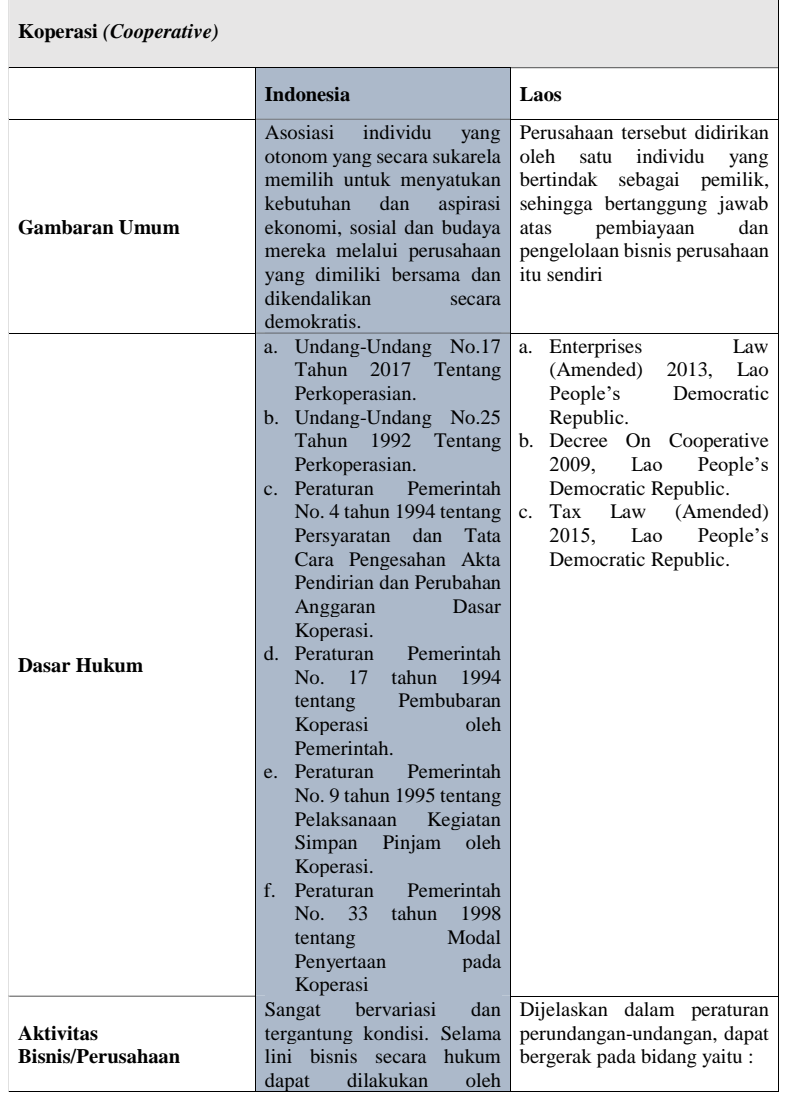

\section{KESIMPULAN}

a. Bentuk hukum dari perusahaan perseorangan (sole proprietorship) tertuang pada "Enterprise Law" Laos yang diamandemen pada tahun 2013. Sedangkan koperasi (cooperative) di Laos bentuk hukumnya berdasarkan pada "Enterprise Law", namun pada peraturan pelaksanaannya tunduk pada ketentuan "Decree On Cooperative" yang dibuat pada tahun 2009.

b. Bentuk hukum dari perusahaan perseorangan (sole proprietorship) di Indonesia ada pada Undang-Undang No.3 Tahun 1982, sedangkan koperasi (cooperative) tertuang dalam UndangUndang No.17 Tahun 2017 Tentang Perkoperasian.

c. Studi komparatif antara perusahaan perseorangan (sole proprietorship) dan koperasi (cooperative) memakai beberapa indikator perbandingan, yaitu sebagai berikut :
- Dasar Hukum

- Aktivitas Perusahaan

- Sumber Permodalan

- Keuntungan

- Kerugian

- Sistem Perpajakan

- Sistem Pembiayaan

\section{SARAN}

a. Menyarankan kepada pemerintah untuk tetap memberikan ruang terhadap UndangUndang atau aturan perlaksanaan perusahaan perseorangan dan koperasi dari segi pengaplikasian undang-undang. Sebagai tambahan, perlu juga untuk melihat kembali isi dari undang-undang perusahaan perseorangan untuk dilakukan amandemen jika diperlukan sesuai dengan tuntutan zaman.

b. Kepada masyarakat untuk mengembangkan induk bisnis dari perusahaan perseorangan dan koperasi agar dapat menjadi sumber penghasilan dan juga sebagai unsur peningkatan sumber daya manusia yang ada.

\section{UNGKAPAN TERIMA KASIH}

Penulis menyampaikan terima kasih yang tak terhingga kepada kedua orangtua penulis yang telah berjasa dalam mendidik penulis hingga saat ini. Terima kasih kepada Rektor Universitas Indonesia beserta seluruh jajaran dosen Program Magister Hukum Fakultas Hukum Universitas Indonesia yang telah memberikan ilmu dan meluangkan waktunya kepada penulis. Serta terima kasih kepada rekan-rekan mahasiswa Pascasarjana Universitas Indonesia, tetap semangat meraih impian.

\section{DAFTAR PUSTAKA}

\section{Buku :}

British Council, 2018, ASEAN Social Enterprise Structuring Guide, New Zealand : UN ESCAP.

Fray dalam Asnawi Hasan, 1987, Koperasi dalam Pandangan Islam, Suatu Tinjauan dari Segi Falsafah Etik, dalam Membangun Sistem Ekonomi Nasional, 
Sistem Ekonomi dan Demokrasi Ekonomi, Jakarta : UI Press.

R.T. Sutantya Rahardja Hadhikusuma, 2005, Hukum Koperasi Indonesia, Jakarta: PT. Raja Grafindo Persada.

Ratnawati Prosodjo, 2007, RUU tentang Usaha Perseorangan dan Badan Usaha Bukan Badan Hukum, Jakarta : Departemen Hukum dan HAM RI.

Sanusi Bintang dan Dahlan, 2000, Pokok-Pokok Hukum Ekonomi dan Bisnis, Bandung : PT. Citra Aditya Bakti.

\section{Undang-Undang :}

Decision on Enterprise Registration 2019, Lao People's Democratic Republik.

Decree On Cooperative 2009, Lao People's Democratic Republic.

Enterprises Law (Amended) 2013, Lao People's Democratic Republic.

Tax Law (Amended) 2015, Lao People's Democratic Republic.

Undang-Undang No.17 Tahun 2017 Tentang Perkoperasian.

Undang-Undang No.3 Tahun 1982 Tentang Daftar Perusahaan.

\section{Artikel :}

http://emerging-marketsresearch.hktdc.com/businessnews/article/ASEAN/A-PracticalGuide-to-Doing-Business-inLaos/asean/en/1/1X000000/1X0ACWH V.htm. Di akses pada tanggal 20 Juli 2020, Pukul 19.01 WITA.

https://home.kpmg/la/en/home/insights/2019/05 /doing-business-in-laos-2019.html. Di akses pada tanggal 21 Juli 2020, Pukul 21.22 WITA. 